MS CANDACE MACHADO DE ANDRADE (Orcid ID : 0000-0003-4467-7016)

MS JESSICA VIEIRA CERQUEIRA (Orcid ID : 0000-0002-5290-2685)

DR RYAN COSTA (Orcid ID : 0000-0003-3075-0729)

DR PHILIP J COOPER (Orcid ID : 0000-0002-6770-6871)

DR CAMILA A FIGUEIREDO (Orcid ID : 0000-0003-1356-6188)

Article type : Commissioned Review or Article

Corresponding author email id: cavfigueiredo@gmail.com

\title{
Parasites and allergy: observations from Brazil
}

Candace Machado de Andrade $^{1}$, Valdirene Leão Carneiro ${ }^{2}$, Jéssica Vieira Cerqueira $^{1}$, Hellen Freitas Fonseca ${ }^{1}$, Gerson de Almeida Queiroz ${ }^{1}$, Ryan do Santos Costa $^{1}$, Neuza Maria Alcantara-Neves ${ }^{1}$, Philip Cooper ${ }^{3,4}$, Camila Alexandrina Figueiredo $^{1}$

${ }^{1}$ Instituto de Ciências da Saúde, Universidade Federal da Bahia, Salvador, Bahia, ${ }^{2}$ Departamento de Ciências da Vida, Universidade do Estado da Bahia, Salvador, Bahia, ${ }^{3}$ St. George's, University of London, London, UK, ${ }^{4}$ Facultad de Ciencias Medicas, de la Salud y la Vida, Universidad Internacional del Ecuador, Quito, Ecuador.

The authors have stated explicitly that there are no conflicts of interest in connection with this article.

\begin{abstract}
Brazil is a middle-income country undergoing the epidemiological transition. Effects of changes in daily life habits, and access to clean water, sanitation and urban services on a growing urban population have contributed to a double burden of both infectious and non-communicable chronic diseases. Studies have indicated that parasite infections may modulate the human immune system and influence the This article has been accepted for publication and undergone full peer review but has not been through the copyediting, typesetting, pagination and proofreading process, which may lead to differences between this version and the Version of Record. Please cite this article as doi: $10.1111 /$ pim. 12588

This article is protected by copyright. All rights reserved.
\end{abstract}


development of allergic conditions such as asthma. However, there is no consensus in the published literature on the effects of parasitic infections on allergy, perhaps as a consequence of factors determining the epidemiology of these infections that vary between populations such as age of first infection, duration and chronicity of infections, parasite burden and species, and host genetic susceptibility. In this review, we discuss the observations from Brazil concerning the relationship between parasite infections and allergy.

Keywords: Parasite, co-infection, allergy/atopy, immune modulation, asthma.

\section{Introduction}

Allergic diseases, autoimmune diseases, and atopy have increased considerably in prevalence globally since the 1970s [1-9]. Allergic reactions are consequent to complex interactions between genetic predisposition and environmental exposures resulting in allergic inflammation and associated with diseases such as allergic rhinitis and allergic asthma $[10,11]$. Atopy is typically associated with a heightened tendency to produce $\mathrm{IgE}$ antibodies in response to common allergens and is accompanied by skin prick test (SPT) reactivity $[12,13]$. Atopy is an immunological phenomenon used to define a disease as allergic (e.g. allergic or atopic asthma) [12].

In Brazil, asthma is an important cause of morbidity and mortality with a significant economic impact, being responsible for about 350,000 hospitalizations annually $[14,15]$. The increased prevalence of immune-mediated diseases has been associated with immune dysfunction and impaired tolerance mechanisms. These immunological alterations have been attributed to a reduction in biodiversity and reduced exposures to a variety of microorganisms and their products [16, 17], consequent to the effects of economic development and industrialization and their associated effects including indoor and outdoor pollution, the increased utilization of chemicals in households, improved hygiene and sanitation, access to infant immunization and widespread use of antibiotics [17-19]. The putative effects of reduced exposures to microbes and their products on immune development and an 
increased risk of inflammatory diseases are described by the hygiene hypothesis [18], relabeled more recently as the biodiversity hypothesis $[4,5,17]$.

The concept of a reduced biodiversity includes effects on all living organisms in all ecosystems including terrestrial, marine and other aquatic ecosystems and related ecological complexes [17].

In Brazil, public health initiatives over the past 80 or so years have led to a decrease in the proportion of total deaths caused by infectious diseases from $50 \%$ to $5 \%$ [20, 21]. Such initiatives have included routine universal immunization of infants and children against an ever increasing number of infectious diseases [22, 23]. In addition, sanitary reform, and social and economic changes have permitted the control or eradication of childhood diarrhea and cholera [24], hepatitis A, Schistosomiasis, Toxoplasma gondii, Herpes simplex, and EBV infections, among many formerly endemic infectious diseases [21]. Similarly, improvements in sanitation and access to anti-parasitic drugs have had dramatic effects on the prevalence of soil transmitted helminth parasites (STH), mainly Ascaris lumbricoides (A. lumbricoides), Trichuris trichiura (T. trichiura), and hookworm (Ancylostoma duodenale and Necator americanus), that were formerly highly prevalent in regions of Brazil with poor access to sanitation and clean water [25]. The potential effects of a reduction in STH prevalence on asthma and atopy have been explored in some detail recently [26].

It has been suggested that parasites such as STH may induce immune regulatory mechanisms in the host and ameliorate aberrant immunological responses that are considered to underlie atopic [27, 28] and autoimmune diseases [29]. The host inflammatory response to parasitic helminths such as STH and schistosome parasites and that documented for atopic conditions have many parallels including a systemic eosinophilia and elevated serum IgE, both of which are hallmarks of a type 2 immune response [30-32]. An ecological study of all municipalities in Brazil reported lower rates of hospitalization for asthma in areas endemic for Schistosoma mansoni or STH [14], indicating that endemic infections with these parasites might contribute to a reduced prevalence and or severity of asthma. 


\section{Impact of sanitation on prevalence of parasitic infections and allergy in Brazil}

Coverage of control strategies for STH parasites is often patchy even in highly endemic countries [33], and is further complicated by high levels of inequality, and variable access to health care facilities, sanitation and potable water [33]. Improvements in sanitation and clean water and hygiene education are highly costeffective public health interventions [34] against infections transmitted through the oral-fecal route [35].

From the 1990s, several federal programs in Brazil were adopted to increase access to sanitation including the Modernization of the Sanitation Sector Program (Programa de Modernização do Setor de Saneamento - PMSS) of 1995. As a consequence of these programs, the supply of piped water to households increased from $32.8 \%$ to $76.6 \%$ while household access to adequate sewage disposal increased from $13.1 \%$ to $46.5 \%$ (Figure $1 \mathrm{~A}$ ). Such strategies may explain the reductions in reported cases of STH infections (Ascaris lumbricoides, Trichuris trichiura, and hookworm) and Schistosoma mansoni at a national level in Brazil (Figure 1B).

In the city of Salvador, capital of Bahia State in Northeast Brazil, a citywide sanitation program, initiated in 1997, increased access to a municipal piped sewer system. Studies from our research group have demonstrated the impact of this intervention on diarrheal incidence and prevalence of STH in children [33, 36, 37]. After implementation of the program, diarrheal prevalence fell by $21 \%$ overall and by $42 \%$ in the most marginalized neighborhoods. Similarly, prevalence rates of STH infections in children of school age declined by $25 \%, 33 \%$ and $82 \%$, for each of Ascaris lumbricoides, Trichuris trichiura and hookworm, respectively. Further, the prevalence of enteric parasitic infections in children aged 0-36 months declined from $24.4 \%$ to $12.0 \%$ for A. lumbricoides, from $18.0 \%$ to $5.0 \%$ for $T$. trichiura, and from $14.1 \%$ to $5.3 \%$ for Giardia intestinalis [37]. These reductions were explained largely by the increased coverage of piped sewage disposal.

To understand better how poor hygiene exposures might mediate their effects on allergy risk through modification of the human cytokine response, we studied the effects of environmental exposures associated with poor hygiene, on cytokine profiles produced by peripheral blood leukocytes (PBLs) either spontaneously or 
upon mitogen stimulation in vitro [38]. The study provided evidence of higher spontaneous IL-10 production by PBLs from children aged up to 8 years in the city of Salvador and living in unfavorable environmental conditions in early life (i.e. no sewage system, potable tap water or garbage collection). This effect was explained by a higher prevalence of STH infections among children living in these unfavorable conditions associated with an allergy-modulating immune regulatory network during childhood [38]. Further analysis within this population showed that chronic STH infections were associated with a generalized suppression of mitogen-induced type 1 and type 2 cytokines, probably explained by enhanced production of spontaneous IL$10[29,39]$. Thus, changes in immune regulation within populations that are related to improvements in sanitary conditions may contribute to an increased prevalence of allergic diseases observed over recent decades in low and middle-income countries such as Brazil [40-42].

An inverse correlation between the prevalence of helminth parasitic infections and asthma can be seen regionally within Brazil between areas with different sanitary and socio-economic conditions: Northern and Northeastern regions with the highest prevalence rates of STH infections also have the lowest prevalence of asthma among adolescents while the converse is seen for the relatively more developed Southern and Central regions (Figure 2)[43, 44]. Differences in per capita income have been related also to asthma prevalence in Brazil. The cities of the Northeast of Brazil such as Maranhão (US\$177), Alagoas (US\$204) and Bahia (US\$239) have lower average monthly incomes than those further South such as Rio Grande do Sul (US\$480) [45].

While epidemiological data have shown temporal trends of a reduced prevalence of helminth parasitic infections and increased allergic disease prevalence, and there are ecologic data to suggest that regions of Brazil with poorer living conditions and a higher prevalence of STH infections have a lower prevalence of asthma, what is the evidence that helminth-associated immune modulation actually affects the prevalence of allergic diseases in Brazil? 


\section{Helminths and allergy in Brazil}

Epidemiological evidence from the published literature for an effect of helminths on allergy is contradictory; while some studies have indicated a positive association with allergy [46, 47], others have not [49,50]. The actual effects of helminths and allergies in a particular population may be affected by a number of factors including the age of first infection, duration and chronicity of infections, parasite burden, the parasite species present and the host genetic background of that population [51]. How may these factors explain the contrasting findings described between different studies in the literature? In this section, we will be discuss, where data are available, how these helminth parasite-related factors may affect allergy in Brazil.

The SCAALA (Social Changes, Asthma and Allergy in Latin America) initiative was set up to understand better the determinants of allergy and allergic diseases in Latin America. Within SCAALA, we have tried to evaluate the relevance of the hygiene hypothesis as an explanation for the epidemiology of allergic diseases in a Brazilian setting in the city of Salvador. An initial observation showed that a high parasite burden with $T$. trichiura infection in early childhood appeared to protect against allergen skin prick test (SPT) reactivity in later childhood, irrespective of whether the child was still infected. Repeated infections (documented on two occasions, in early and later childhood) were associated with the lowest prevalence of SPT in later childhood [28]. In contrast, infections with T. trichiura and allergic sensitization to Ascaris (i.e. having specific anti-Ascaris $\lg \mathrm{E}$ antibodies) were associated with an increased risk of atopic wheezing [52].

Human infections with $A$. lumbricoides are considered to induce immune modulation and increased IgE production, the latter occurring through IL-4-mediated polyclonal activation of plasma cells producing lgE against parasite and non-parasite allergens [53-55]. Parasite-targeted IgE antibodies produced during infections with A. lumbricoides have been shown to cross-react with self or environmental allergens [56] such as tropomyosin [55, 57-60]. False-positive tests for IgE against environmental aeroallergens is a concern among parasite-exposed populations and might explain the reported association between anti-Ascaris $\lg \mathrm{E}$ and atopic wheeze [52], although it does not explain the oberved association with wheeze, independent 
of atopy, defined here by the presence of serum $\lg E$ antibodies against at least one allergen. The association between anti-Ascaris IgE and wheeze, which was not seen for the presence of $A$. lumbricoides eggs in stool samples [52], could be related to allergic inflammatory responses against Ascaris larvae migrating through the lungs, known as Loeffler's Syndrome [61].

We also observed, in the same study population in Salvador, a marked dissociation between levels of allergen-specific IgE and SPT to the same allergen such that many more children had detectable levels of specific lgE compared to SPT [62]. There are several explanations for this dissociation such as competition between polyclonal and specific $\operatorname{lgE}$ for binding to high-affinity receptors on mast cells $[63,64]$ and host genetic factors [62], among others. Additional studies are required to identify the mechanisms underlying this association $[55,57]$.

A previous meta-analysis of cross-sectional studies of the associations between STH infections and asthma, reported a positive association between the microscopic detection of $A$. lumbricoides infection in fecal samples and prevalence of asthma symptoms, while hookworm infection was associated with a reduced asthma prevalence [65]. Similarly a meta-analysis of cross-sectional studies showed an inverse association between STH infections and the prevalence of atopy defined by SPT positivity [66]. These meta-analyses included studies from Brazil, among which was one from southern Brazil showing that children with a higher parasite burden with $A$. lumbricoides (defined as $\geq 100$ eggs/gram of feces) had a higher risk of bronchial hyperresponsiveness (BHR) compared to uninfected children and those with lower parasite burdens [67] This association may reflect airways inflammation and BHR secondary to Loeffler's Syndrome. Taken together, these results suggest that STH parasites may have contrasting effects on wheezing and atopy depending on parasite species, timing or duration of infection and parasite burden. Further studies are required to identify the mechanisms by which such effects occur.

Chronic infections and co-infections are thought to be more strongly associated with the presence of parasite-specific IgG4 antibodies. Children with chronic STH infections have elevated levels of anti-A. lumbricoides $\lg G 4$ and also greater ratios of parasite-specific $\lg G 4$ to $\operatorname{lgE}$ antibodies than do those with infections detected at only a single time point. Elevated levels of parasite-specific IgG4 may be explained 
by increased production of IL-10 during chronic STH infections that enhances subclass switching to IgG4 compared to IgE [29, 39]. An analysis of effects of pathogen burden on allergy markers, showed that children infected with a larger number of chronic pathogen infections including STH, bacteria and viruses had a reduced risk of having SPT and allergen-specific IgE but not asthma compared to those with fewer infections [42] Moreover, using an unbiased cluster analysis approach called latent class analysis, it was observed that children living in better environmental conditions, having better educated mothers and a lower burden of childhood infections, were more likely to have a 'immune responsive' phenotype and a greater risk of atopy, measured by specific IgE and SPT positivity to aeroallergens [41]. Similarly, children infected with a greater number of helminth species were more likely to have evidence of stronger immune regulation (i.e increased IL-10 production by PBLs) and reduced risk of atopy defined, in this case, as the presence of aeroallergen-specific $\operatorname{lgE}$ irrespective of SPT results [68]. These observations are consistent with the hypothesis that the induction of 'appropriate' immune regulation by chronic pathogens may protect against atopy [27]. Host genetic background may also contribute to immune regulation; we have described polymorphisms in the IL10 gene that are associated with reduced IL-10 production by PBLs stimulated with A. lumbricoides antigens and that in turn are associated with protection against helminth infections and a greater risk of atopic wheeze and markers of allergy (i.e SPT response and allergen-specific IgE level) [69]. Further, individuals with certain TGF- $\beta$ polymorphisms appear to have an increased susceptibility to $T$. trichiura and A. lumbricoides infections and a lower risk of developing allergy [70].

As for STH infections, human infections with the cosmopolitan helminth parasitic infection, Toxocara, has been associated with allergy in humans [71-75]. Toxocara is a zoonotic infection that is unable to develop to adulthood in the human host. The infection is caused by contact with an environment contaminated with feces from dogs infected with Toxocara canis and cats with Toxocara cati [72]. Human infections with the larval stages of Toxocara spp. may last for years and have been associated with significant morbidity related to allergic inflammatory responses directed against larvae in tissues [51]. 
Several studies in Brazil have investigated the effects of human infections with Toxocara on allergy and allergic diseases. In the Amazon region in Northern Brazil, Ferreira and collaborators, observed a positive association between Toxocara spp. infection and wheezing in a sample of children aged 6-59 months [76]. We have reported in the SCAALA cohort, an association between the presence of antiToxocara spp IgG and eosinophilia, elevated levels of total IgE and antiaeroallergen-IgE [32] but an inverse association with SPT and no association with asthma symptoms. Similarly, in a different population of 6-11 year olds near Salvador in the State of Bahia with a Toxocara seropositivity rate of $65 \%$, positive associations were observed between seropositivity and eosinophilia and antiaeroallergen-lgE, but no association with asthma [77]. In the SCAALA study population Toxocara seropositivity appeared to be a strong effect modifier of the association between anti-aeroallergen- $\lg \mathrm{E}$ and that may, in part, explain the dissociation between the two markers of atopy (SPT and $\operatorname{lgE}$ ). [32]. Similar effect modification has been observed for infections with $A$. lumbricoides and $T$. trichiura in the same population [62]. A possible explanation for such effect modification by helminth infections might be the presence of low-affinity antibodies to helminths that cross-react with arthropod allergens $[58,59]$. Such low affinity $\lg E$ might have limited biological activity (i.e. for the activation of mast cells).

Immune regulation induced in host by helminth infections appears to modulate type 1 in addition to type 2 responses. A potent down-modulation of both type 1 and type 2 responses has been observed in individuals infected with Schistosoma mansoni (S. mansoni), a water-borne parasite of humans, which causes chronic infections [78]. A characteristic feature of chronic infections with $S$. mansoni is the activation of IL-10 producing regulatory $T$ and $B$ cells [79-81]. A study in the state of Bahia, showed that peripheral blood mononuclear cells (PBMCs) from S. mansoniinfected asthmatics produced lower levels of IL-5 and IL-4 but higher levels of IL-10 in response to $D$. pteronyssinus antigen compared to those of uninfected asthmatics before anthelmintic treatment [81]. Following treatment, half the infected asthmatics suffered a deterioration of asthma symptoms that was accompanied by a decline in PBMC IL-10 production [81]. 
A relatively high production of IL-10 by PBMCs from asthmatics infected with S. mansoni has been documented in other studies from Brazil [82] in which alternatively IL-10 producing activated monocytes/macrophages and CD4+CD25+ T cells appear to be involved in the downmodulation of inflammatory responses in asthmatics [83].

Asthmatics infected with S. mansoni appear to have a lower frequency of SPT and a more benign form of the disease compared to uninfected asthmatics also living in rural areas [84]. Even in a setting of low endemicity in Brazil, it appears that $S$. mansoni infection may reduce the risk of SPT positivity to one or more antigens [85]. In a study of the role of host genetics in determining susceptibility to schistosomiasis, significant heritability was observed both for total serum $\lg E$ levels (60\%) and host egg count with S. mansoni (31\%), although the specific genetic markers associated with these effects were not identified [86]. This study demonstrated that, in the context of a population where the primary environmental stimulus for type 2 immune pathways (measured indirectly by total $\lg \mathrm{E}$ ) was helminth infection, the regulation of host immunity was also likely to be due to host genetic factors. A study of subjects co-infected with hookworm and $S$. mansoni have shown an increase in levels of antiDer $\mathrm{p} 1 \mathrm{lg} \mathrm{E}$ levels following chemotherapy, an effect that was independent of parasite burden [87].

Human lymphatic filariasis, still present in parts of northern Brazil, causes chronic infections in humans that may persist for many years, and is associated with a profound modulation of host anti-parasite immune responses [88, 89]. A study of individuals with lymphatic filariasis with and without antigenemia showed higher frequencies of IFN- $\gamma$ - and IL-4-producing $\mathrm{CD}^{+} \mathrm{T}$ cells among patients without evidence of circulating microfilariae in the blood, consistent with a down-regulation of immune responses among patients with patent infections [90] observed previously in non-Brazilian populations [91, 92]. Despite such immune modulation in patent lymphatic filariasis, a recent study in Brazilian adolescents with combinations of Wuchereria bancrofti infection and allergic disease, was unable to identify evidence of an effect of infection on SPT positivity or Th2 cytokine responses to Der $p 1$ [93]. 
Another aspect of interest relating to helminth-allergy interactions is the potential effects of treatments for allergic diseases on parasite infections, such as the well-known but rare cases of Strongyloides hyperinfection syndrome developing in infected individuals taking oral corticosteroids as a consequence of uncontrolled replication of Strongyloides stercoralis larvae within the human host [26]. Immune mechanisms related to type 2 immune responses are considered to play a key role in protective immunity against helminth parasite infections [94]. Among such mediators of type-2 associated inflammatory responses, $\lg E$ is considered to have an important role [95]. The use of humanized monoclonal antibodies directed against IgE (anti$\lg \mathrm{E}$, Omalizumab - Xolair, ${ }^{\mathrm{TM}}$ ) to treat allergic disease has raised the concern that such treatment might increase susceptibility to infection or increased parasite burdens. However, a randomized controlled trial to study the possibility of increased susceptibility to STH parasites among allergic patients receiving anti-lgE treatment, was unable to identify evidence of increased susceptibility to STH infections among patients receiving anti-lgE. [96]. The same concerns, however, are relevant for the use of new biological drugs (e.g. anti-IL-5) targeting different components of type-2 inflammatory pathways [26].

In summary, data from Brazilian studies have contributed important data that have informed our understanding of parasite-allergy interactions, although further studies are required to understand better the mechanisms by which helminths may modulate allergic responses. The epidemiologic data show that helminth parasites in the context of other childhood infectious diseases do appear to modulate atopy although the effects on allergic diseases are less clear. A better understanding of these mechanisms will help define the potential role of helminth-product derived therapies in the treatment of inflammatory conditions.

\section{Protozoa and allergy in Brazil}

The prevalence of intestinal protozoa infections is greater than that of helminth infections in Brazil [97-102]. These parasites are unicellular organism that during acute infections, induce a type 1 immune response, that is essential to control parasite replication [103-105]. 
Giardia lamblia elicits both a cellular and humoral immune response, inducing cytokines such as tumor necrosis factor (TNF) [106], interferon (IFN)-y [107, 108] and interleukin (IL)-17 [109], as well as, nitric oxide (NO) [110], production of antigiardial IgA antibodies [111, 112] and intestinal mastocytosis [113, 114]. The relationship between giardiasis and allergy has been considered in the context of food allergy and allergic skin diseases [107, 115-117]. Studies in Brazil have addressed associations between giardiasis, total $\operatorname{lgE}$ and respiratory allergic symptoms [118, 119]. A cross-sectional study of children in Recife in Northern Brazil showed no association between $G$. lamblia and respiratory allergies [118].

Another protozoan parasite, T. gondii, has been extensively studied with respect to allergic sensitization in both murine models and humans [42, 103, 120 124]. Inverse associations have been observed in Brazilian populations between seropositivity for $T$. gondii and atopy (measured as both SPT and serum IgE to aeroallergens) $[42,123]$. Although the mechanism whereby this modulation occurs is not well understood, data from murine models have shown that allergic inflammation can be suppressed by treating animals with Toxoplasma extract or derived proteins [125-127].

\section{Concluding remarks}

Many host and parasite factors are likely to play a role in determining the effects of parasites in the modulation of allergic inflammation. Urbanization and improvements in sanitation have been associated with temporal and geographical trends of increasing allergic disease prevalence in Brazil even though a large proportion of the population continues to live in conditions of poverty. Latin American countries, including Brazil, are currently experiencing a shift to non-communicable conditions, such as allergies and asthma, termed the epidemiological transition. Findings on the parasite-allergy interaction from human populations in Brazil remain contradictory and there is a need for more studies using standardized definitions for allergy outcomes and new approaches such as studies of epigenetic mechanisms related to parasite exposure. 


\section{References}

[1] Bach J-F. The Effect of Infections on Susceptibility to Autoimmune and Allergic Diseases. N Engl J Med 2002; 347: 911-920.

[2] Holgate ST, Wenzel S, Postma DS, et al. Asthma. Nat Rev Dis Prim 2015; 1: 15025.

[3] Rook GAW. Review series on helminths, immune modulation and the hygiene hypothesis: the broader implications of the hygiene hypothesis. Immunology 2009; 126: 3-11.

[4] Hanski I, von Hertzen L, Fyhrquist N, et al. Environmental biodiversity, human microbiota, and allergy are interrelated. Proc Natl Acad Sci U S A 2012; 109: 8334-9.

[5] von Hertzen L, Hanski I, Haahtela T. Natural immunity. Biodiversity loss and inflammatory diseases are two global megatrends that might be related. $E M B O$ Rep 2011; 12: 1089-93.

[6] Nakagomi $\mathrm{T}$, Itaya $\mathrm{H}$, Tominaga $\mathrm{T}$, et al. Is atopy increasing? Lancet (London, England) 1994; 343: 121-2.

[7] Steinegger L, Regenass S, Bachmann LM, et al. Atopy and related clinical symptoms among Swiss medical students from 2007 to 2015. Allergy Asthma Clin Immunol 2018; 14: 4.

[8] O'Connell EJ. The burden of atopy and asthma in children. Allergy 2004; 59: $7-11$.

[9] Bernard A, Carbonnelle S, de Burbure C, et al. Chlorinated pool attendance, atopy, and the risk of asthma during childhood. Environ Health Perspect 2006; 114: 1567-73.

[10] Cooper PJ. Intestinal worms and human allergy. Parasite Immunol 2004; 26: 455-467.

[11] Sitcharungsi R, Sirivichayakul C. Allergic diseases and helminth infections. Pathog Glob Health 2013; 107: 110-5.

[12] Suh DI, Koh YY. Relationship between atopy and bronchial 
hyperresponsiveness. Allergy Asthma Immunol Res 2013; 5: 181-8.

[13] Santiago H da C, Nutman TB. Role in Allergic Diseases of Immunological Cross-Reactivity between Allergens and Homologues of Parasite Proteins. Crit Rev Immunol 2016; 36: 1-11.

[14] Ponte E, Franco RA, Souza-Machado A, et al. Impacto de um programa para o controle da asma grave na utilização de recursos do Sistema Único de Saúde. J Bras Pneumol 2007; 33: 15-19.

[15] Cooper PJ, Rodrigues LC, Cruz AA, et al. Asthma in Latin America: a public heath challenge and research opportunity. Allergy 2009; 64: 5-17.

[16] Rook GAW. The hygiene hypothesis and the increasing prevalence of chronic inflammatory disorders. Trans R Soc Trop Med Hyg 2007; 101: 1072-1074.

[17] Haahtela T, Holgate S, Pawankar R, et al. The biodiversity hypothesis and allergic disease: world allergy organization position statement. World Allergy Organ J 2013; 6: 3.

[18] Strachan DP. Hay fever, hygiene, and household size. BMJ 1989; 299: 125960.

[19] Yazdanbakhsh M, Kremsner PG, van Ree R. Allergy, parasites, and the hygiene hypothesis. Science 2002; 296: 490-4.

[20] Monteiro CA. Contribuição para o estudo do significado da evolução do coeficiente de mortalidade infantil no município de São Paulo, SP (Brasil) nas três última décadas (1950-1979). Rev Saude Publica 1982; 16: 7-18.

[21] Barreto ML, Teixeira MG, Bastos FI, et al. Successes and failures in the control of infectious diseases in Brazil: social and environmental context, policies, interventions, and research needs. Lancet (London, England) 2011; 377: 1877-89.

[22] Olivé J-M, Jr. JBR, Quadros CA de. National Immunization Days: Experience in Latin America. The Journal of Infectious Diseases 1997; 175: S189-93.

[23] de Quadros CA, Tambini G, DiFabio JL, et al. STATE OF IMMUNIZATION IN THE AMERICAS. Infect Dis Clin North Am 2000; 14: 241-257. 
[24] Brasil. Ministério da Saúde. In: MANUAL INTEGRADO DE VIGILÂNCIA EPIDEMIOLÓGICA DA CÓLERA. Brasília, p. 170.

[25] Bethony J, Brooker S, Albonico M, et al. Soil-transmitted helminth infections: ascariasis, trichuriasis, and hookworm. Lancet (London, England) 2006; 367: 1521-32.

[26] Cruz AA, Cooper PJ, Figueiredo CA, et al. Global issues in allergy and immunology: Parasitic infections and allergy. J Allergy Clin Immunol 2017; 140: 1217-1228.

[27] Guarner F, Bourdet-Sicard R, Brandtzaeg P, et al. Mechanisms of Disease: the hygiene hypothesis revisited. Nat Clin Pract Gastroenterol Hepatol 2006; 3: 275-284.

[28] Rodrigues LC, Newcombe PJ, Cunha SS, et al. Early infection with Trichuris trichiura and allergen skin test reactivity in later childhood. Clin Exp Allergy 2008; 38: 1769-1777.

[29] Figueiredo CA, Barreto ML, Rodrigues LC, et al. Chronic intestinal helminth infections are associated with immune hyporesponsiveness and induction of a regulatory network. Infect Immun 2010; 78: 3160-7.

[30] Pulendran B, Artis D. New paradigms in type 2 immunity. Science 2012; 337: 431-5.

[31] Mingomataj EC, Xhixha F, Gjata E. Helminths can protect themselves against rejection inhibiting hostile respiratory allergy symptoms. Allergy 2006; 61: 400406.

[32] Mendonça LR, Veiga RV, Dattoli VCC, et al. Toxocara seropositivity, atopy and wheezing in children living in poor neighbourhoods in urban Latin American. PLoS Negl Trop Dis 2012; 6: e1886.

[33] Mascarini-Serra LM, Telles CA, Prado MS, et al. Reductions in the prevalence and incidence of geohelminth infections following a city-wide sanitation program in a Brazilian Urban Centre. PLoS Negl Trop Dis 2010; 4: e588.

[34] Fewtrell L, Kaufmann RB, Kay D, et al. Water, sanitation, and hygiene interventions to reduce diarrhoea in less developed countries: a systematic 
review and meta-analysis. Lancet Infect Dis 2005; 5: 42-52.

[35] Laxminarayan R, Mills AJ, Breman JG, et al. Advancement of global health: key messages from the Disease Control Priorities Project. Lancet (London, England) 2006; 367: 1193-208.

[36] Barreto ML, Genser B, Strina A, et al. Effect of city-wide sanitation programme on reduction in rate of childhood diarrhoea in northeast Brazil: assessment by two cohort studies. Lancet (London, England) 2007; 370: 1622-8.

[37] Barreto ML, Genser B, Strina A, et al. Impact of a citywide sanitation program in Northeast Brazil on intestinal parasites infection in young children. Environ Health Perspect 2010; 118: 1637-42.

[38] Figueiredo CA, Alcântara-Neves NM, Veiga R, et al. Spontaneous cytokine production in children according to biological characteristics and environmental exposures. Environ Health Perspect 2009; 117: 845-849.

[39] Figueiredo CA, Alcantara-Neves NM, Amorim LD, et al. Evidence for a modulatory effect of IL-10 on both Th1 and Th2 cytokine production: The role of the environment. Clin Immunol 2011; 139: 57-64.

[40] Kliś K, Żurawiecka M, Suder A, et al. Influence of Socioeconomic Factors on Self-Reported Prevalence of Allergic Diseases Among Female University Students. Springer, Cham, pp. 17-24.

[41] Figueiredo CA, Amorim LD, Alcantara-Neves NM, et al. Environmental conditions, immunologic phenotypes, atopy, and asthma: New evidence of how the hygiene hypothesis operates in Latin America. J Allergy Clin Immunol 2013; 131: 1064-1068.e1.

[42] Alcantara-Neves NM, Veiga RV, Dattoli VCC, et al. The effect of single and multiple infections on atopy and wheezing in children. J Allergy Clin Immunol 2012; 129: 359-67, 367.e1-3.

[43] Início - DATASUS, http://datasus.saude.gov.br/ (accessed 1 March 2018).

[44] Kuschnir FC, Gurgel RQ, Solé D, et al. ERICA: prevalence of asthma in Brazilian adolescents. Rev Saude Publica 2016; 50 Suppl 1: 13s. 
[45] IBGE :: Instituto Brasileiro de Geografia e Estatística, https://ww2.ibge.gov.br/home/estatistica/indicadores/trabalhoerendimento/pna d_continua/default_renda_percapita.shtm (accessed 1 March 2018).

[46] Pereira MU, Sly PD, Pitrez PM, et al. Nonatopic asthma is associated with helminth infections and bronchiolitis in poor children. Eur Respir J 2007; 29 : 1154-60.

[47] Webb EL, Nampijja M, Kaweesa J, et al. Helminths are positively associated with atopy and wheeze in Ugandan fishing communities: results from a crosssectional survey. Allergy 2016; 71: 1156-69.

[48] Hagel I, Cabrera M, Hurtado MA, et al. Infection by Ascaris lumbricoides and bronchial hyper reactivity: An outstanding association in Venezuelan school children from endemic areas. Acta Trop 2007; 103: 231-241.

[49] Cooper PJ, Barreto ML, Rodrigues LC. Human allergy and geohelminth infections: a review of the literature and a proposed conceptual model to guide the investigation of possible causal associations. Br Med Bull 2006; 79-80: 203-218.

[50] Wördemann M, Diaz RJ, Heredia LM, et al. Association of atopy, asthma, allergic rhinoconjunctivitis, atopic dermatitis and intestinal helminth infections in Cuban children. Trop Med Int Heal 2008; 13: 180-186.

[51] Cooper PJ. Interactions between helminth parasites and allergy. Curr Opin Allergy Clin Immunol 2009; 9: 29-37.

[52] Alcântara-Neves NM, Badaró SJ, dos Santos MCA, et al. The presence of serum anti-Ascaris lumbricoides IgE antibodies and of Trichuris trichiura infection are risk factors for wheezing and/or atopy in preschool-aged Brazilian children. Respir Res 2010; 11: 114.

[53] Caraballo L, Acevedo N. New Allergens of Relevance in Tropical Regions: The Impact of Ascaris lumbricoides Infections. World Allergy Organ J 2011; 4: 7784.

[54] Cooper PJ, Chico ME, Rodrigues LC, et al. Reduced risk of atopy among school-age children infected with geohelminth parasites in a rural area of the 
tropics. J Allergy Clin Immunol 2003; 111: 995-1000.

[55] Medeiros D, Silva AR, Rizzo JA, et al. Total lgE level in respiratory allergy: study of patients at high risk for helminthic infection. J Pediatr (Rio J) 2006; 82: 255-259.

[56] Pontes-de-Carvalho L, Mengel J, Figueiredo CA, et al. Antigen mimicry between infectious agents and self or environmental antigens may lead to long-term regulation of inflammation. Front Immunol 2013; 4: 314.

[57] Sarinho ES, Medeiros D, Silva A, et al. Specific IgE Anti-Ascaris in Brazilian Children and Adolescents. World Allergy Organ J 2010; 3: 53-6.

[58] Santos ABR, Rocha GM, Oliver C, et al. Cross-reactive lgE antibody responses to tropomyosins from Ascaris lumbricoides and cockroach. J Allergy Clin Immunol 2008; 121: 1040-6.e1.

[59] Acevedo N, Sánchez J, Erler A, et al. IgE cross-reactivity between Ascaris and domestic mite allergens: the role of tropomyosin and the nematode polyprotein ABA-1. Allergy 2009; 64: 1635-1643.

[60] Acevedo N, Erler A, Briza P, et al. Allergenicity of Ascaris lumbricoides tropomyosin and IgE sensitization among asthmatic patients in a tropical environment. Int Arch Allergy Immunol 2011; 154: 195-206.

[61] REEDER WH, GOODRICH BE. PULMONARY INFILTRATION WITH EOSINOPHILIA (PIE SYNDROME). Ann Intern Med 1952; 36: 1217.

[62] Alcantara-Neves NM, Veiga R V, Ponte JCM, et al. Dissociation between skin test reactivity and anti-aeroallergen IgE: Determinants among urban Brazilian children. PLoS One 2017; 12: e0174089.

[63] Ponte JC, Junqueira SB, Veiga R V, et al. A study on the immunological basis of the dissociation between type I-hypersensitivity skin reactions to Blomia tropicalis antigens and serum anti-B. tropicalis IgE antibodies. BMC Immunol 2011; 12: 34.

[64] Carvalho $\mathrm{K}$ dos A, de Melo-Neto OP, Magalhães FB, et al. Blomia tropicalis Blo t 5 and Blo t 21 recombinant allergens might confer higher specificity to serodiagnostic assays than whole mite extract. BMC Immunol 2013; 14: 11. 
[65] Leonardi-Bee J, Pritchard D, Britton J, et al. Asthma and Current Intestinal Parasite Infection. Am J Respir Crit Care Med 2006; 174: 514-523.

[66] Feary J, Britton J, Leonardi-Bee J. Atopy and current intestinal parasite infection: a systematic review and meta-analysis. Allergy 2011; 66: 569-578.

[67] da Silva ER, Sly PD, de Pereira MU, et al. Intestinal helminth infestation is associated with increased bronchial responsiveness in children. Pediatr Pulmonol 2008; 43: 662-665.

[68] Alcântara-Neves NM, de S G Britto G, Veiga RV, et al. Effects of helminth coinfections on atopy, asthma and cytokine production in children living in a poor urban area in Latin America. BMC Res Notes 2014; 7: 817.

[69] Figueiredo CA, Barreto ML, Alcantara-Neves NM, et al. Coassociations between IL10 polymorphisms, IL-10 production, helminth infection, and asthma/wheeze in an urban tropical population in Brazil. J Allergy Clin Immunol 2013; 131: 1683-90.

[70] Costa RDS, Figueiredo CA, Barreto ML, et al. Effect of polymorphisms on TGFB1 on allergic asthma and helminth infection in an African admixed population. Ann Allergy Asthma Immunol 2017; 118: 483-488.e1.

[71] Guilherme E V., Marchioro AA, Araujo SM, et al. Toxocariasis in children attending a Public Health Service Pneumology Unit in Paraná State, Brazil. Rev Inst Med Trop Sao Paulo 2013; 55: 189-192.

[72] Despommier D. Toxocariasis: clinical aspects, epidemiology, medical ecology, and molecular aspects. Clin Microbiol Rev 2003; 16: 265-72.

[73] Gonzalez-Quintela A, Gude F, Campos J, et al. Toxocara infection seroprevalence and its relationship with atopic features in a general adult population. Int Arch Allergy Immunol 2006; 139: 317-24.

[74] Zacharasiewicz A, Auer H, Brath H, et al. [Toxocara and bronchial hyperreactivity--results of a seroprevalence study]. Wien Klin Wochenschr 2000; 112: 922-6.

[75] Sharghi N, Schantz PM, Caramico L, et al. Environmental Exposure to Toxocara as a Possible Risk Factor for Asthma: A Clinic-Based Case-Control 
Study. Clin Infect Dis 2001; 32: e111-e116.

[76] Ferreira MU, Rubinsky-Elefant G, de Castro TG, et al. Bottle feeding and exposure to Toxocara as risk factors for wheezing illness among under-five Amazonian children: a population-based cross-sectional study. J Trop Pediatr 2007; 53: 119-24.

[77] Silva MB, Amor ALM, Santos LN, et al. Risk factors for Toxocara spp. seroprevalence and its association with atopy and asthma phenotypes in school-age children in a small town and semi-rural areas of Northeast Brazil. Acta Trop 2017; 174: 158-164.

[78] Pearce EJ, MacDonald AS. The immunobiology of schistosomiasis. Nat Rev Immunol 2002; 2: 499-511.

[79] Layland LE, Straubinger K, Ritter M, et al. Schistosoma mansoni-Mediated Suppression of Allergic Airway Inflammation Requires Patency and Foxp3+ Treg Cells. PLoS Negl Trop Dis 2013; 7: e2379.

[80] van der Vlugt LEPM, Labuda LA, Ozir-Fazalalikhan A, et al. Schistosomes Induce Regulatory Features in Human and Mouse CD1dhi B Cells: Inhibition of Allergic Inflammation by IL-10 and Regulatory T Cells. PLoS One 2012; 7 : e30883.

[81] Araujo MIAS, Hoppe B, Medeiros, Jr. M, et al. Impaired T Helper 2 Response to Aeroallergen in Helminth- Infected Patients with Asthma. J Infect Dis 2004; 190: 1797-1803.

[82] Cardoso LS, Oliveira SC, Pacífico LG, et al. Schistosoma mansoni antigendriven interleukin-10 production in infected asthmatic individuals. Mem Inst Oswaldo Cruz 2006; 101: 339-343.

[83] Oliveira RR, Gollob KJ, Figueiredo JP, et al. Schistosoma mansoni infection alters co-stimulatory molecule expression and cell activation in asthma. Microbes Infect 2009; 11: 223-229.

[84] Medeiros M, Figueiredo JP, Almeida MC, et al. Schistosoma mansoni infection is associated with a reduced course of asthma. J Allergy Clin Immunol 2003; 111: 947-51. 
[85] Oliveira SM de, Bezerra FS de M, Carneiro TR, et al. Association between allergic responses and Schistosoma mansoni infection in residents in a lowendemic setting in Brazil. Rev Soc Bras Med Trop 2014; 47: 770-774.

[86] Grant AV, Araujo MI, Ponte EV, et al. High Heritability but Uncertain Mode of Inheritance for Total Serum IgE Level and Schistosoma mansoni Infection Intensity in a Schistosomiasis- Endemic Brazilian Population. J Infect Dis 2008; 198: 1227-1236.

[87] Campolina SS, Araujo MSS, Rezende TMRL, et al. Effective anthelmintic therapy of residents living in endemic area of high prevalence for Hookworm and Schistosoma mansoni infections enhances the levels of allergy risk factor anti-Der p1 lgE. Results Immunol 2015; 5: 6-12.

[88] HOERAUF A, SATOGUINA J, SAEFTEL M, et al. Immunomodulation by filarial nematodes. Parasite Immunol 2005; 27: 417-429.

[89] Nutman TB, Kumaraswami V. Regulation of the immune response in lymphatic filariasis: perspectives on acute and chronic infection with Wuchereria bancrofti in South India. Parasite Immunol 2001; 23: 389-399.

[90] de Almeida AB, Silva MC, Braga C, et al. Differences in the frequency of cytokine-producing cells in antigenemic and nonantigenemic individuals with bancroftian filariasis. Infect Immun 1998; 66: 1377-83.

[91] Mahanty S, Luke HE, Kumaraswami V, et al. Stage-Specific Induction of Cytokines Regulates the Immune Response in Lymphatic Filariasis. Exp Parasitol 1996; 84: 282-290.

[92] King CL, Mahanty S, Kumaraswami V, et al. Cytokine control of parasitespecific anergy in human lymphatic filariasis. Preferential induction of a regulatory T helper type 2 lymphocyte subset. J Clin Invest 1993; 92: 1667-73.

[93] Aguiar-Santos AM, Montenegro S, Medeiros Z, et al. Immunomodulation of allergic response in children and adolescents: What we can learn from lymphatic filarial infection. Allergol Immunopathol (Madr). Epub ahead of print February 2018. DOI: 10.1016/j.aller.2017.09.023.

[94] Cooper PJ, Ayre G, Martin C, et al. Geohelminth infections: a review of the role 
of $\lg \mathrm{E}$ and assessment of potential risks of anti-lgE treatment. Allergy 2008; 63: 409-417.

[95] Zaph C, Cooper PJ, Harris NL. Mucosal immune responses following intestinal nematode infection. Parasite Immunol 2014; 36: 439-52.

[96] Cruz AA, Lima F, Sarinho E, et al. Safety of anti-immunoglobulin E therapy with omalizumab in allergic patients at risk of geohelminth infection. Clin Exp Allergy 2007; 37: 197-207.

[97] Faria CP, Zanini GM, Dias GS, et al. Geospatial distribution of intestinal parasitic infections in Rio de Janeiro (Brazil) and its association with social determinants. PLoS Negl Trop Dis 2017; 11: e0005445.

[98] Henrique C, Fonsêca A, Marques BC, et al. ENTEROPARASITES, RESPIRATORY ALLERGY AND OTHER SIGNS AND SYMPTOMS IN CHILDS AND YOUTH POPULATION OF RECÔNCAVO OF BAHIA - BRAZIL. J Adv Allergy Immunol Dis; 12. Epub ahead of print 2018. DOI: 10.25177/JAAID.2.1.5.

[99] Coelho CH, Durigan M, Leal DAG, et al. Giardiasis as a neglected disease in Brazil: Systematic review of 20 years of publications. PLoS Negl Trop Dis 2017; 11: e0006005.

[100] Teixeira JC, Heller L, Barreto ML. Giardia duodenalis infection: risk factors for children living in sub-standard settlements in Brazil. 2007; 23: 1489-1493.

[101] Silva RR, da Silva CAM, de Jesus Pereira CA, et al. Association between nutritional status, environmental and socio-economic factors and Giardia lamblia infections among children aged 6-71 months in Brazil. Trans $R$ Soc Trop Med Hyg 2009; 103: 512-519.

[102] Escobar-Pardo ML, Godoy APO de, Machado RS, et al. Prevalence of intestinal parasitoses in children at Parque Indígena do Xingu. J Pediatr (Rio J); 0. Epub ahead of print 10 November 2010. DOI: 10.2223/JPED.2036.

[103] Wagner A, Förster-Waldl E, Garner-Spitzer E, et al. Immunoregulation by Toxoplasma gondii infection prevents allergic immune responses in mice. Int $J$ Parasitol 2009; 39: 465-472. 
[104] Raetz M, Hwang S-H, Wilhelm CL, et al. Parasite-induced TH 1 cells and intestinal dysbiosis cooperate in IFN- $\gamma$-dependent elimination of Paneth cells. Nat Immunol 2012; 14: 136-142.

[105] Gazzinelli RT, Denkers EY. Protozoan encounters with Toll-like receptor signalling pathways: Implications for host parasitism. Nat Rev Immuno/ 2006; 6: 895-906.

[106] Zhou P, Li E, Shea-Donohue T, et al. Tumour necrosis factor alpha contributes to protection against Giardia lamblia infection in mice. Parasite Immunol 2007; 29: 367-74.

[107] Bayraktar MR, Mehmet N, Durmaz R. Serum cytokine changes in Turkish children infected with Giardia lamblia with and without allergy: Effect of metronidazole treatment. Acta Trop 2005; 95: 116-122.

[108] Matowicka-Karna J, Dymicka-Piekarska V, Kemona H. IFN-gamma, IL-5, IL-6 and IgE in patients infected with Giardia intestinalis. Folia Histochem Cytobiol 2009; 47: 93-97.

[109] Saghaug CS, Sørnes S, Peirasmaki D, et al. Human Memory CD4+ T Cell Immune Responses against Giardia lamblia. Clin Vaccine Immunol 2015; 23 : $11-8$.

[110] Eckmann L, Laurent F, Langford TD, et al. Nitric Oxide Production by Human Intestinal Epithelial Cells and Competition for Arginine as Potential Determinants of Host Defense Against the Lumen-Dwelling Pathogen Giardia lamblia. J Immunol 2000; 164: 1478-1487.

[111] Heyworth MF. Intestinal IgA responses to Giardia muris in mice depleted of helper T lymphocytes and in immunocompetent mice. J Parasitol 1989; 75: 246-251.

[112] Langford TD, Housley MP, Boes M, et al. Central importance of immunoglobulin A in host defense against Giardia spp. Infect Immun 2002; 70: $11-8$.

[113] Li E, Zhou P, Petrin Z, et al. Mast cell-dependent control of Giardia lamblia infections in mice. Infect Immun 2004; 72: 6642-9. 
[114] Li E, Tako EA, Singer SM. Complement Activation by Giardia duodenalis Parasites through the Lectin Pathway Contributes to Mast Cell Responses and Parasite Control. Infect Immun 2016; 84: 1092-9.

[115] Di Prisco MC, Hagel I, Lynch NR, et al. Association between giardiasis and allergy. Ann Allergy Asthma Immunol 1998; 81: 261-5.

[116] Farthing MJG, Chong SKF, Walker-Smith JA. Acute allergic phenomena in giardiasis. Lancet 1983; 322: 1981.

[117] Giacometti A, Cirioni O, Antonicelli L, et al. Prevalence of Intestinal Parasites Among Individuals With Allergic Skin Diseases. J Parasitol 2003; 89: 490-492.

[118] Souza VMO, Sales IRF, Peixoto DM, et al. Giardia lamblia and respiratory allergies: a study of children from an urban area with a high incidence of protozoan infections. J Pediatr (Rio J). Epub ahead of print 23 May 2012. DOI: 10.2223/JPED.2184.

[119] Geller M, Geller M, Flaherty DK, et al. Serum IgE levels in giardiasis. Clin Allergy 1978; 8: 69-71.

[120] Fenoy I, Giovannoni M, Batalla E, et al. Toxoplasma gondii infection blocks the development of allergic airway inflammation in BALB/c mice. Clin Exp Immunol 2009; 155: 275-84.

[121] Janse JJ, Wong GWKK, Potts J, et al. The association between foodborne and orofecal pathogens and allergic sensitisation - EuroPrevall study. Pediatr Allergy Immunol 2014; 25: 250-256.

[122] Fenoy IM, Sánchez VR, Soto AS, et al. Toxoplasma gondii infection modulate systemic allergic immune response in BALB/c mice. Exp Parasitol 2015; 154 : 47-50.

[123] Fernandes JFC, Taketomi EA, Mineo JR, et al. Antibody and cytokine responses to house dust mite allergens and Toxoplasma gondii antigens in atopic and non-atopic Brazilian subjects. Clin Immunol 2010; 136: 148-56.

[124] Jeong Y II, Hong SH, Cho SH, et al. Toxoplasma gondii Infection Suppresses House Dust Mite Extract-Induced Atopic Dermatitis in NC/Nga Mice. Allergy Asthma Immunol Res 2015; 7: 557-64. 
[125] Drinić M, Wagner A, Sarate $P$, et al. Toxoplasma gondii tachyzoite-extract Acts As a Potent Immunomodulator Against Allergic Sensitization and Airway Inflammation. Sci Rep 2017; 7 : 1-12.

[126] Soto AS, Fenoy IM, Sanchez VR, et al. Toxoplasma gondii serine-protease inhibitor-1: A new adjuvant candidate for asthma therapy. PLoS One 2017; 12: e0187002.

[127] Wagner A, Schabussova I, Drinic M, et al. Oocyst-Derived Extract of Toxoplasma Gondii Serves as Potent Immunomodulator in a Mouse Model of Birch Pollen Allergy. PLoS One 2016; 11: e0155081.

\section{Figure legends}

Figure 1. (A) Demographic census data from the Brazilian Institute of Geography and Statistics (IBGE)[45] between 1991 and 2010 showing improvements in sanitary conditions such as supply of piped water, sewage collection network and garbage collection. (B) Data from the Department of Informatics of the Unified Health System (DATASUS)[43] from Brazil for the Control Program of Schistosomiasis (PCE). Data is shown for reported infections with Schistosomasp. and the soil-transmitted helminthes, Ascaris lumbricoides, Trichuris trichiura, and hookworm between 2002 and 2016. Both surveys were conducted in the north, northeast, southeast, south and central-west regions of Brazil.

Figure 2. Map of Brazil showing the five principal geographic regions. Circles represent the positivity rate in 2011 for Ascaris lumbricoides, Trichuris trichiura and hookworm infections, from the Department of Informatics of the Unified Health System (DATASUS). Different shades of green shown for each region represent the estimated prevalence of current asthma among adolescents (12 to 17 years) observed in the ERICA study [44]. 

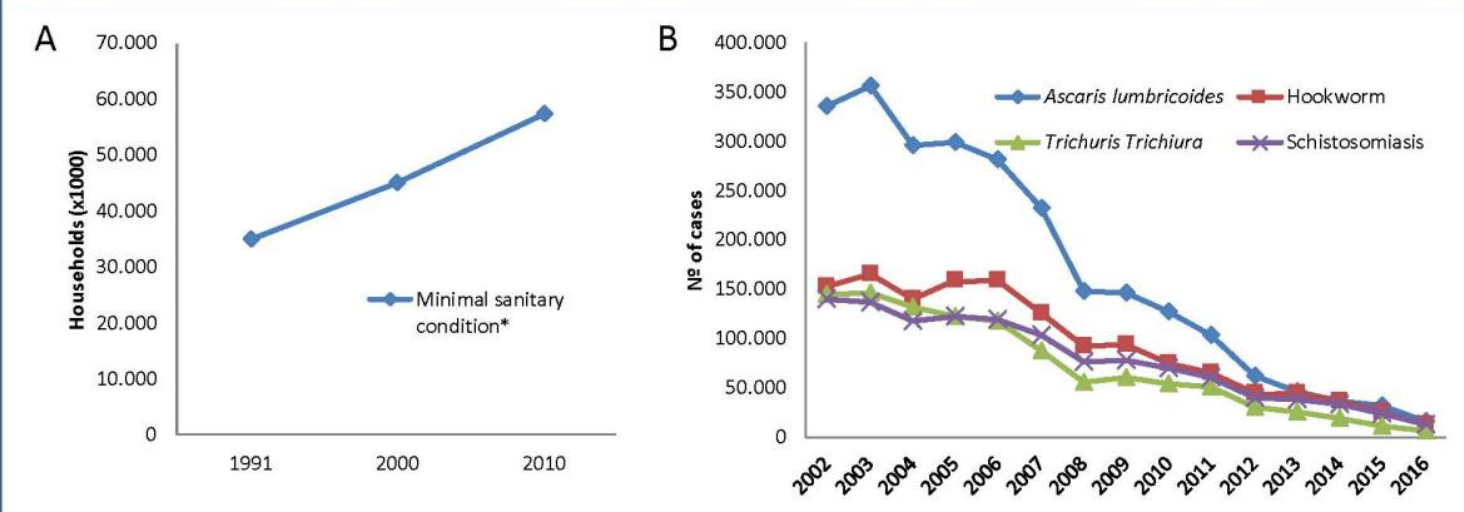

This article is protected by copyright. All rights reserved. 


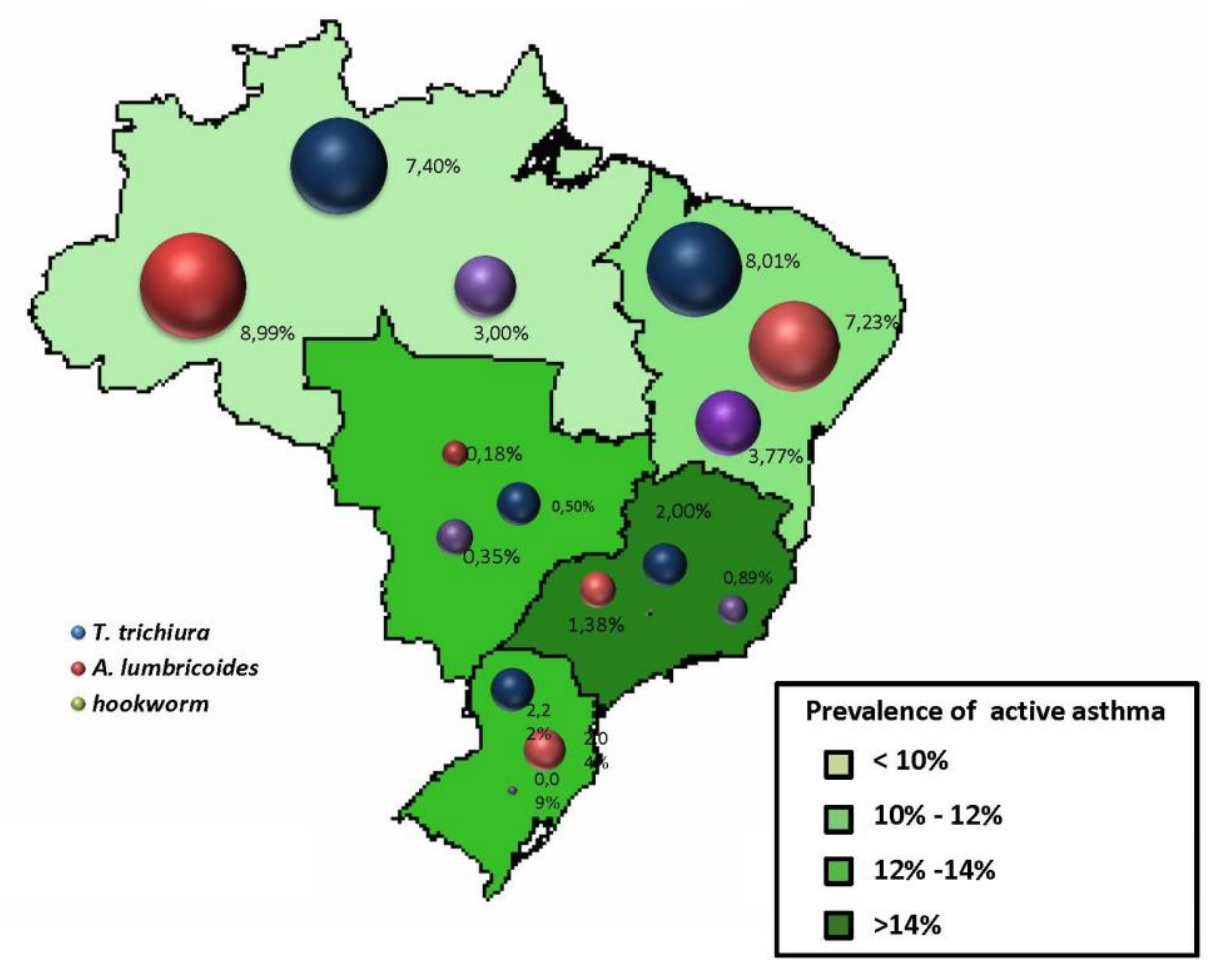

This article is protected by copyright. All rights reserved. 